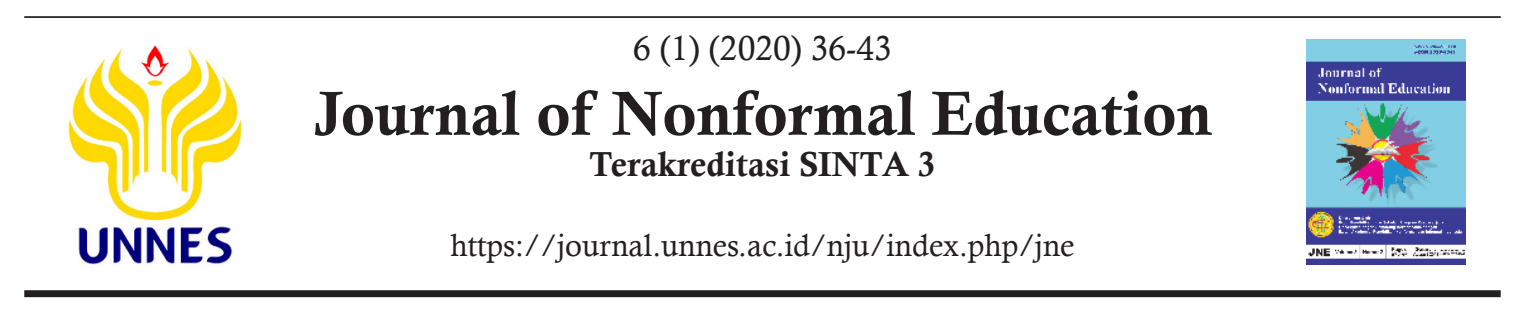

\title{
The Transformation of Sustainable Community Empowerment Based on Islamic Boarding Schools System
}

\author{
Elih Sudiapermana ${ }^{\bowtie}$, Muslikhah
}

DOI: http://dx.doi.org/10.15294/jne.v6i1.23429

Universitas Pendidikan Indonesia, Indonesia

\section{History Article}

Submitted 18 August 2019 Revised 24 January 2020 Accepted 4 February 2020

\section{Keywords}

ecological literacy; civil society; sharia economy; character transformation

\begin{abstract}
Community empowerment and education are closely related to advancing society. The purpose of this study was to analyze the implementation and transformation of sustainable community empowerment based on Islamic boarding school system. This is due to the assumption that Islamic boarding school, as a sharia economic developer, gives several impacts on training entrepreneurship, independence of santri, and prosperity of the society. This research used a qualitative method with the phenomenological approach from Edmund Husserl. Phenomenology or transcendental phenomenology aims to find the existence of consciousness essence (intentionality) which consists of four awareness activities. The results of this study indicate that the community empowerment in Al-Ittifaw Islamic boarding school refers to environmental use. The school also adopts an experiential learning and learning by doing system. These systems accustomed the students to learn, maintain, and preserve nature. The agribusiness development of Al-Ittifaq Islamic Boarding School is based on INPEKBI (Divine, Domestic, Personal, Economic, Family, Passion, Ilmihi) principle. The conclusion of this paper is, several stages are needed in terms of raising awareness, habituation, and reinforcement to build the entrepreneurial spirit during the transformation of sustainable community empowerment based on Islamic boarding school system.
\end{abstract}

Correspondence Author:

E-mail: elsud@upi.edu
p-ISSN 2442-532X

e-ISSN 2528-4541 


\section{INTRODUCTION}

Rapid technological advancements provide an extraordinary impact on globalization in the world of education and community empowerment. Educational information systems have evolved to keep up with technological developments in the world of education (GonzálezSancho \& Vincent-Lancrin, 2016). Community empowerment and education are closely related to advancing society. Community empowerment will improve society's economy. Empowerment occupies a central position in the efforts of community-based health education (Holden et al., 2005); (Zimmerman, 2000) and this shows how community organizations can be sustainable in that empowerment (Hughey et al., 2008). In present days, community empowerment also began to be developed in Islamic boarding schools. In general, these boarding schools have 3 functions: (a) Center of Excellence for religious thinkers; (b) Institutions that develop human resources; (c) Agent of Development for community empowerment (Rusmini, 2019). Thus, Islamic boarding schools are always making improvements to compete in today's globalization world. In this way the community can achieve their goals, and the process can be in various ways by making choices without changing people's ideology (Lawson, et al., 2014) that the buildings on the factor for all the society.

Islamic boarding schools are one of the non-formal education units with religious education as their main foundation. With regard to success in his life, not only think of the world but also think of the Hereafter (Shofwan, et al., 2019). According to (Al-Hamdani, et al., 2015), Islamic boarding schools are religious institutions that cannot be released from society, especially rural communities, because it grows and develops from and for the community. Islamic boarding schools sometimes get bad assumptions from various parties due to their educational foundation. A student needs to have a discipline of learning by doing exercises and strengthening himself to always be accustomed to complying with and heightens self- control, so that the acquired abilities can be repeated with relatively equal results (Shofwan, et al., 2019). Community empowerment through the establishment of business groups and sharia economics is an effort to eliminate the bad perceptions of Islamic boarding schools. There is a relationship in potential the potential for Islamic finance contracts for services which are the main driving force of Islamic finance systems and guidelines for Islamic finan- ce operations (Lone, et al., 2016).

Al-Ittifaq Islamic boarding school received various highlights from the government because of its success in community empowerment. Islamic economics as an alternative solution to economic system activities upholds the values of ownership, justice, freedom, balance, brotherhood, and togetherness (Ade, 2009). It can be seen that Islamic boarding schools, as non-formal education, can develop in accordance with current development and balancing the application of religious, educational, social, and cultural sciences. In addition, these schools also began to develop community empowerment through Islamic economics to improve the economy of the community. The construction of Islamic financial foundations has involved about a new landscape in the financial system (Diaw, 2011) .

Community empowerment from Islamic boarding schools has its own appeal to get people involved. These schools have the potential to foster human character that has faith, morals, and readiness for the globalization challenges. Thus, these non-formal education units are suitable to prevent negative impacts of technological developments. Sighting and then doing things oneself, with prominent lessons accomplished through one's error, one go along in practical learning (Dar \& Najar, 2018). In addition, innovation for empowerment makes Islamic boarding schools as a part of the whole economic system around its surroundings. According to (Ubaidillah, 2010) posits that globalization and economy have been incorporated into society. As a result, many young people fall into negative environments or behaviors. Therefore, the role of Islamic boarding schools to fortify the younger generation from globalization attacks is urgently needed.

The data in the field reveals that Al-Ittifaq Islamic boarding school used the ecological literacy principle which applied in accordance with the conditions of the society around the boarding school. Al-Ittifaq Islamic boarding school has 3 principles that are always applied to all students that (1) the ground shall not be empty; (2) The garbage shall not be scattered; (3) time cannot be wasted. The three simple principles are applied to all members of the Islamic boarding school. This kind of environment makes an efficient community. The surrounding society uses the environment to grow crops, then the results are used and managed to produce high economic value. This learning process is obtained through learning by doing system. The lessons learned became a productive cycle for the farmers up to this day. When an individual does not have productivity, the va- 
lue of education obtained is limited (Bol, 2015). Indonesian education in one of its writings shows how much innovation is needed in learning within both formal and non-formal education in building a Nation (Ardiwinata, \& Hasanah, 2016). Based on the explanation above, research to the implementation and transformation of a boarding school-based for sustainable community empowerment system is needed. It is important because Islamic boarding schools are considered to have a role as a sharia economic developer in training entrepreneurship, independence of sant$r i$, and prosperity of the community. The system used in the Al-Ittifaq Islamic boarding school is expected to be adopted by other Islamic boarding schools. Hence, an independent civil society will be formed by developing sustainable community empowerment through entrepreneurship based on Islamic boarding schools.

Community empowerment based on Islamic boarding schools is an empowerment which inserts religious values in each of the empowerment activities. This empowerment promoting Islamic education as the foundation in empowering the community. There is a lot of literature that focuses on differences in each country with community institutional characteristics, such as the education system and various labor market institutions (Diaw, 2011), (Bol \& Werfhorst, 2013). Islamic education aims to form al-insani al-kamil or complete men. It is also directed at two dimensions, namely horizontal dialectical dimension towards each other and vertical dimension towards submission to God (Nizar, 2016). In other words, this community empowerment horizontally improves the economic condition of Islamic boarding schools' surroundings and also vertically bring each individual closer to the ultimate creator of Allah SWT.

\section{METHODS}

This research used a qualitative method with the phenomenological approach of Edmund Husserl. Phenomenology or transcendental phenomenology aims to find the existence of consciousness essence (intentionality) which consists of four awareness activities. The activities include objectivity, identification, correlation and constitution (Soerjono, 2012). This study applied a descriptive study where a researcher tries to describe the research activities on certain objects clearly and systematically. The researchers tried to deepen understanding on the social meanings that emerge in the environment of the research object, find patterns, and hypothesis by using the- ories to study the object of research (Sugiyono, 2011).

This research used a descriptive qualitative method with purposive sampling. The participants of this study were 5 persons from the Al-Ittifaq boarding school. The participants were as follows: FD (Head of Al-Ittifaq boarding school), AP (business manager of Al-Ittifaq boarding school), DE (alumni of Al-Ittifaq boarding school and member of farmers), QW (a farmer from local people), GH (student or santri in AlIttifaq boarding school). FD, AP, DE, and DE were used as primary data while QW and $\mathrm{GH}$ participations were used as secondary data

The data were collected through interview and observation. It also used several instrument tools, including interviews guides, observation sheets, notes from the interviews result, and documents analysis.

This research used an inductive approach with an interactive model data analysis. There are four important components of qualitative analysis in this study, including data collection, data reduction, data display, and data conclusion along with verification.

The following is the framework for understanding the concepts in this study:

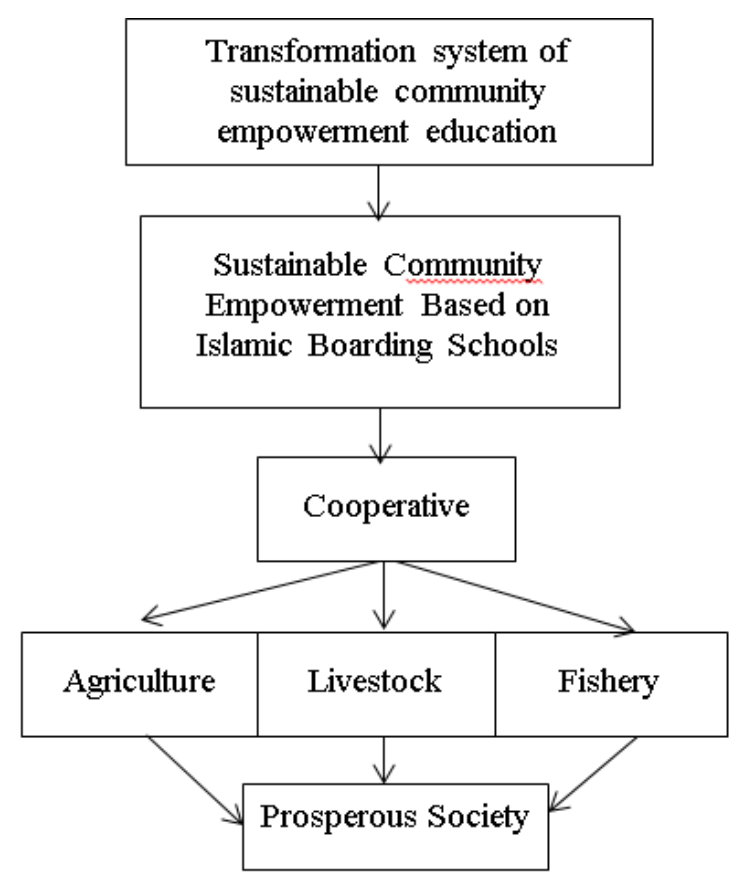

Figure 1. Conceptual Framework

\section{RESULTS AND DISCUSSION}

Al-Ittifaq Islamic Boarding School is located in Ciburial, Alam Endah Village 02/10, Rancabali District, South Bandung, West Java 
Province. The distance from the boarding school to the nearest district is $\pm 9 \mathrm{~km}$, while regional government pavilion is $\pm 32 \mathrm{~km}$ and $\pm 43 \mathrm{~km}$ to Bandung city. The administrative area of Alam Endah Village is around 506.6 ha and is inhabited by around 22,673 inhabitants. Al-Ittifaq Islamic Boarding School was founded in 1934 by $\mathrm{KH}$. Mansyur with Kanjeng Dalem Wiranata Kusumah blessings. At the beginning of its establishment, Al-Ittifaq Islamic boarding school was classified as a traditional Salafiyah boarding school; no involvement of other education than religious education. Throughout those early ages, the applied education in Al-Ittifaq was only related to the understanding of religion from $\mathrm{Al}$-Quran or its recitation, the yellow book (Kitab Kuning), and Sunnah Wal Jamaah activities. It provide not opportunities in expressing perspectives and knowledge related to education not being democratic, irrational, emotional intelligence and mental health (Jones, 2018) and some pathways link education with mental health (Bracke, et al., 2014).

In 1970, Al-Ittifaq boarding schools underwent drastic changes under KH. Fuad Affandi leadership. The Salafiyah education system changed into Khalafiyah due to the consideration of current development. In this context, most are described in terms of opposition through the term (Jarosz, 2014). Leadership not only applies their leadership but also instills leadership values and ethics which are the main principles of leadership in becoming effective leadership (Fairholm \& Gronau, 2015; Kalman, et al., 2016; Noor, et al., 2018). Indicators of success in effective leadership can be seen from the interpretation of programs effectively and efficiently through the support of all members (Arifin, et al., 2018). Salafiyah education system in Al-Ittifaq allows its students to follow or equalize formal education. This was started from the possibility of not all graduates from Islamic boarding schools will become a religious thinker. KH. Fuad began debriefing skills to his students with the agricultural business that adjusted the natural potential from the school environment. The development of agribusiness extended into agriculture and fishery which further empower the surrounding community and become the backbone of Al-Ittifaq boarding school.

The term transformation refers to the process of changing. Indonesian Language Dictionary $(\mathrm{KBBI})$ asserts transformation means changes in form, nature, function and so on (Alya, 1997). It can be seen from the explanation above that transformation is a change that refers to a reality which serves to create a better change of state.
Transformation is a process of changing that has characteristics as follows: (a) the difference is the most important aspect of the transformation process, (b) the concept of characteristic or identity is a reference for differences in a transformation process. If something is said to be different, then the transformation process has taken place. However, different things must be clearly compared, for examples, social characteristics, particular concepts (including economics, thoughts, or other ideas) or the application characteristics of a concept, (3) Historically, the transformation process always describes the differences in historical conditions (different conditions at different times) (Dewi, 2012). Therefore, education requires a transformation of system that has quality innovations to solve problems in the education world. Each faction discusses ways to change economic practices to be in line with religious teachings (Botoeva, 2018).

Empowerment can be interpreted as empowering or strengthening (Theresia, 2014). According to Edi Suharto, empowerment is a series of activities to strengthen power or empowering weak groups in society, including individuals who experience problems of poverty (Suharto, 2010). Meanwhile, Jim Ife as quoted by Zubaedi explains that empowerment is providing resources, opportunities, knowledge, and skills to the citizen. It will help the societies to determine, participate, and influence their own future $(\mathrm{Zu}-$ baedi, 2007). Empowerment means developing strength or ability (power), potential, resources, human beings in order to defend them (Dianto, 2018). In summary, the general goal of community empowerment is to empower the community according to the best potential of human or natural resources in order to live independently.

The sustainable community empowerment program is a substitute program for the national community empowerment program (PNPM). This government program substantially seeks to reduce poverty with the concept of community empowerment. The community is expected to actively participate in the decision making and problem-solving. Other studies show differences in each country, group, and historical shifts related to education and health (Dianto, 2018; Miech et al., 2011; Subramanian et al., 2010).

Community empowerment refers to environmental use. Al-Ittifaq Islamic boarding school adopts an experiential learning and learning by doing system. These systems accustomed the students to learn, maintain, and preserve nature. The agribusiness development of Al-Ittifaq Islamic Boarding School is based on INPEKBI (Divine, 
Domestic, Personal, Economic, Family, Passion, Ilmihi) principle. It means that the implementation process of agribusiness development must be blessed by Allah SWT, recognized by the government (country), virtuous, and profitable. The empowerment provides multiple effects on santri and the surrounding society of Al-Ittifaq Islamic boarding schools. One of the effects is sustainable empowerment for santri and virtuous society with entrepreneurial skills.

Agribusiness conducted by Al-Ittifaq Islamic boarding school includes agriculture, fishery, and livestock. This boarding school has approximately 18 hectares of land which is managed for agribusiness land and the needs of Islamic boarding schools. Al-Ittifaq also has a good marketing by cooperating with minimarkets and supermarkets around Bandung. They perform planting, packaging, labeling, and marketing with a highlevel standard which was learned from learning by doing strategy. This is justified by FD, the head of Al-Ittifaq Islamic boarding school: "at the beginning of this agribusiness, I started it all with trial and error. Then, I went to Germany and Netherland to learn something new. By then, I think Indonesia is a very rich and fertile country because we can plant almost anything. Unfortunately, people are lazy to manage the existing land."

Empowering people to take part in programs at Al-Ittifaq is not easy. Many people still used traditional principles by selling crops to middleman or directly to the market. Formed integration of the value of variation in truth in the context and culture in organizational resources is a fact that must be considered to be sought (Arifin et al., 2018). Therefore, the school provides examples of agricultural business work firstly. This is affirmed by DE: "at the beginning, this Islamic boarding school only studied religion, especially Salafiyah. In the middle of the time, Ulema thought about the future of Al-Ittifaq Islamic boarding school and graduates. Where do they want to be after graduating? From there, an entrepreneurial briefing for santri was given, thus, they will not be unemployed in the future time. Then, agribusiness began to develop, and many local people joined in eventually". Another justification also came from AP, business manager in Al-Ittifaq boarding school. "Being in a position like now is not as easy as it seems. A lot of processes are needed before society finally wants to be involved and collaborate with this boarding school".

This community empowerment was initially only carried out by farmers around Islamic boarding schools because they felt uncomfortable to refuse the head of Al-Ittifaq. After experience better profits than selling the crops to middlemen or markets, where the selling price goes up and down uncontrollably, they began to continuously sell the crops to the cooperation of Al-Ittifaq. It gives more benefits for the local because Islamic boarding schools cooperation also provides all the necessity of farmers from fertilizer, financial capital, seeds, agricultural medicines, and even basic daily needs with a system of cutting payments after harvest. Soon, many farmers from inside and outside the village asked to join AlIttifaq boarding school. Nine farmer groups were formed and centered on the boarding school. Each group has 25-30 farmer members. The benefits from agribusiness are not only perceived by farmer group members but also by the santri, as GH points out: " $i$ have never paid any money in here. It is okay for me to work without salary, as long as I get to eat twice a day, clothes, and shelter, I am grateful".

Starting from this, Al-Ittifaq became an example of boarding school which succeeded in building community empowerment-based on Islamic boarding school. Community empowerment is conducted routinely in a form of regular coaching every two weeks. The meeting was used as a discussion forum for the farmers and disseminate information regarding new types of agriculture that have high selling prices. The farmers will be accompanied by Al-Ittifaq students while planting new types of agriculture to minimalize failure. The activities in regular coaching include religious education which is also the foundation for community empowerment implementation. QW, a member of the farmer group clarifies this: "Coaching is routinely held every two weeks. Other than gathering with Ulema and other farmers, Al-Quran recitation and discussion were usually conducted. Therefore, we were not only chasing temporal things but also eternal or hereafter".

This empowerment has changed the community prosperity around Al-Ittifaq Islamic boarding schools. A good empowerment management system by the boarding school minimizes losses and crop failures. This is due to the school regulation of changing cropping system. It strictly must be adhered by farmer groups to maintain soil fertility. As informed by DE as alumni of farmer members: "after graduating, I was given venture capital by the boarding school with a profit-sharing system for return on capital. The planted crops are always monitored by AlIttifaq to prevent harvest failure". QW, a member of the farmer group, also adds: "By following the regulation of crop changing from Al-Ittifaq, the 
soil becomes more fertile. Moreover, mixed sari system is also taught in Al-Ittifaq Islamic boarding schools to utilize the whole land properly ".

Besides alternating different planting systems, all agricultural products must be utilized optimally to support livestock and fisheries. The availability of vegetables that will be distributed to supermarkets is always sufficient because it is well-managed by the Islamic boarding school. The applied management organization looks simple but various positive and beneficial impacts can be used by the school and the community. A statement from AP as the manager of Al-Ittifaq boarding school strengthens the above explanation. "we all learn from experience, thus there is no need to put many theories on it. Just apply it first and then taught the results to the rest far- mer groups. Nowadays, the farmer groups are far more prosperous than they were before. As long as they follow the advice from Al-Ittifaq, there is a small percentage for harvest failure". At this point, the sustainable community empowerment based on Islamic boarding school will show its transformation. The farmers who only applied traditional farming began to adopt modern farming systems that are environmentally friendly.

The community also began to send their children into higher levels of education in hopes of improving the prosperity for the society and serve the Islamic boarding school. Excepts being taught an agricultural system, farmers are also taught other strategies to enhance the development in livestock and fishery. For instance, livestock's manures are utilized and processed

Table 1. Activities of Al-Ittifaq's Santri

\begin{tabular}{|c|c|}
\hline \multicolumn{2}{|l|}{ General Activities } \\
\hline Activities & Description \\
\hline \multicolumn{2}{|l|}{ Daily Activities } \\
\hline Al-Quran Recitation & Reading the Qur'an and/or the Sunnah after congregation prayer \\
\hline Tandzif & Cleaning activity in the morning around Al-Ittifaq Boarding School \\
\hline Congregational Prayer & Praying altogether in the mosque's school. \\
\hline \multicolumn{2}{|l|}{ Weekly Activities } \\
\hline Muhadloroh & Public speaking training for santri every Thursday night. \\
\hline $\begin{array}{l}\text { Al-Quran Recitation for } \\
\text { Public }\end{array}$ & $\begin{array}{l}\text { Qur'an recitation with santri and surrounding society every Mon- } \\
\text { day night. }\end{array}$ \\
\hline Physical Exercise & Physical Exercise every Friday and Sunday. \\
\hline Diba'an & Salawat every Thursday night. \\
\hline Tahfidz Qur'an & Al-Qur'an memorization activities every Friday to Sunday. \\
\hline \multicolumn{2}{|l|}{ Montly Activities } \\
\hline Recitation/ Ta'lim & Ta'liim for santri and surrounding society every once in a month. \\
\hline \multicolumn{2}{|l|}{ Annual Activities } \\
\hline Haflatul Imtihanut & Graduation and celebration of grade or level movement. \\
\hline $\begin{array}{l}\text { Tahriri Commemoration of } \\
\text { Islamic Day }\end{array}$ & Commemorate Islamic holidays. \\
\hline Mass Khitan (Circumcision) & Free mass circumcision for indigent people every Rajab month. \\
\hline \multicolumn{2}{|l|}{ Agribusiness Activities } \\
\hline Agriculture & $\begin{array}{l}\text { An activity of cultivating the land, planting horticulture, and har- } \\
\text { vesting the crops. }\end{array}$ \\
\hline Ranch & $\begin{array}{l}\text { An activity of nursing the livestock and processing animal feed } \\
\text { along with its manure. }\end{array}$ \\
\hline Fishery & An activity of rearing and processing fishes until it is ready for sale. \\
\hline Post-harvest Processing & $\begin{array}{l}\text { An activity in to storage the harvest products. It includes the pro- } \\
\text { cess of sorting, grading packing, wrapping, and labeling. }\end{array}$ \\
\hline Marketing & Product distribution activity to the market and other stores. \\
\hline Cooperation & $\begin{array}{l}\text { The center of all Al-Ittifaq agribusiness units to manage adminis- } \\
\text { tration and finance by santri. }\end{array}$ \\
\hline
\end{tabular}


into biogas to fulfill surrounding household needs, silage fermentation in animal food to fatten the livestock and increase the selling prices, and distilled water system from household wastewater. These applied environmentally friendly systems in Al-Ittifaq is explained by QW, a member of the farmer group. "After being taught by the Islamic boarding school, I learned more about farming. It is not only about growing vegetables but also raising livestock. Now, I can support my family without shortages".

The empowerment that has been carried out by Islamic boarding schools has reflected the transformed education to santri and society for a lifelong and sustainable education. The transformation of sustainable community empowerment based on Islamic boarding school is oriented towards improving the prosperity of society. The offered programs are directed vertically (submission to God) and horizontally (prosperity enhancement for society) to an independent civil society. Consequently, the programs from Islamic boarding schools, especially Al-Ittifaq, are accepted by society. The following is students' regular activities at Al-Ittifaq Islamic Boarding School. The programs contain all of the activities for students during their studies at Al-Ittifaq Islamic Boarding School. The activities are divided into two categories, namely general activities and agribusiness activities.

Table 1 show the general and agribusiness programs for the students at Al-Ittifaq Islamic boarding school. The general activities are related to the learning of religious education which also involves the surrounding society. On the other hand, agribusiness activities are everyday activities that focusing on disciplinary, increasing agribusiness knowledge, and create the entrepreneurial spirit for the santri.

\section{CONCLUSION}

From the explanation above, it can be concluded that the transformation system of sustainable community empowerment based on Islamic boarding schools, especially in Al-Ittifaq, runs in accordance with learning by doing system. Al-Ittifaq Islamic Boarding School has based its principle on INPEKBI (Divine, Domestic, Personal, Economy, Family, Passion, and Ilmihi). It means that the implementation process of agribusiness development must be blessed by Allah SWT, recognized by the government (country), virtuous, and profitable. The applied management organization looks simple but various positive and beneficial impacts are already perceived by the school and the surrounding community. The implementation of sustainable community empowerment goes through several stages, including: (1) Business training; (2) Venture Capital; (3) Mentoring; and (4) Marketing. Islamic economy continuously cycling throughout those stages.

Based on the conducted research at the Al-Ittifaq Islamic Boarding School related to the transformation system of sustainable community empowerment education, there are several suggestions to improve the advancement in Al-Ittifaq Islamic boarding school. The suggestions are as follows: (1) the management structure of the institution should be managed more neatly, thus every tasks and responsibility for the individual are clearly distinctive. (2) the administrative management should be organized further to confirm the organizational structure of the Al-Ittifaq Islamic boarding school.

\section{REFERENCES}

Ade, M. (2009). Ekonomi Syariah Peluang dan Tantangan Bagi Ekonomi Indonesia. Al-Iqtishad: Jurnal Ilmu Ekonomi Syariah, 1(1), 107-112.

Al-Hamdani, M. D., Ibrahim, T., \& Thoyyar, H. (2015). Pengembangan kepemimpinan transformasional pada lembaga pendidikan Islam. Nuansa Aulia.

Alya, Q. (1997). Kamus Besar Bahasa Indonesia. Indahjaya Adipratama.

Arifin, I., Juharyanto, Mustiningsih, \& Taufiq, A. (2018). Islamic Crash Course as a Leadership Strategy of School Principals in Strengthening School Organizational Culture. SAGE Open, 8(3), 2158244018799849. https://doi.org/10. $1177 / 2158244018799849$

Bol, T., \& Van de Werfhorst, H. G. (2013). Educational systems and the trade-off between labor market allocation and equality of educational opportunity. Comparative Education Review, 57(2), 285-308.

Bol, T. (2015). Has education become more positional? Educational expansion and labour market outcomes, 1985-2007. Acta Sociologica (United Kingdom), 58(2), 105-120. https://doi. org/10.1177/0001699315570918

Botoeva, A. (2018). Islam and the spirits of capitalism: Competing articulations of the islamic economy. Politics and Society, 46(2), 235-264. https:// doi.org/10.1177/0032329218776014

Bracke, P., Van De Straat, V., \& Missinne, S. (2014). Education, mental health, and education-labor market misfit. Journal of Health and Social Behavior, 55(4), 442-459.

Dar, W. A., \& Najar, I. A. (2018). Educational Anthropology, Tribal Education and Responsible Citizenship in India. South Asia Research, 38(3), 327346. https://doi.org/10.1177/0262728018800 759 
Elih Sudiapermana et al. / Journal of Nonformal Education 6 (1) (2020) 36-43

Diaw, A. (2011). The global financial crisis and Islamic finance : a review of selected literature. Munich Personal RePEc Archive, 1(1), 1-14.

Dianto, I. (2018). Peranan Dakwah dalam Proses Pengembangan Masyarakat Islam. Jurnal Hikmah, 12(1), 98-118.

Dewi, E. (2012). Transformasi Sosial dan Nilai Agama. Substantia, 14(1), 112-121.

Fairholm, M. R., \& Gronau, T. W. (2015). Spiritual leadership in the work of public administrators. Journal of Management, Spirituality and Religion, 12(4), 354-373. https://doi.org/10.1080/1476 6086.2015.1060516

González-Sancho, C., \& Vincent-Lancrin, S. (2016). Transforming education by using a new generation of information systems. Policy Futures in Education, 14(6), 741-758. https://doi. org/10.1177/1478210316649287

Holden, D. J., Evans, W. D., Hinnant, L. W., \& Messeri, P. (2005). Modeling psychological empowerment among youth involved in local tobacco control efforts. Health Education and Behavior, 32(2), 264-278. https://doi. org/10.1177/1090198104272336

Hughey, J., Peterson, N. A., Lowe, J. B., \& Opres$\mathrm{cu}, \mathrm{F}$. (2008). Empowerment and sense of community: Clarifying their relationship in community organizations. Health Education and Behavior, 35(5), 651-663. https://doi. org/10.1177/1090198106294896

Jajat S. Ardiwinata, Viena Rusmiati Hasanah, E. S. (2016). Model Pelatihan Berbasis Nilai Keagamaan Dalam Membentuk Karakter Generasi Muda. Journal of Nonformal Education, 2(1), 49-56. https://doi.org/10.15294/jne.v2i 1.5312

Jarosz, L. (2014). Comparing food security and food sovereignty discourses. Dialogues in Human $\mathrm{Ge}$ ography, 4(2), 168-181.

Kalman, M., \& Arslan, M., C. (2016). School principals' evaluations of their instructional leadership behaviours: Realities vs. ideals. School Leadership \& Management, 36(5), 508-530.

Lawson, L., \& Kearns, A. (2014). Rethinking the purpose of community empowerment in neighbourhood regeneration: The need for policy clarity. Local Economy, 29(1-2), 65-81.

Lone, F. A., Lone, F., \& Lone, F. A. (2016). Islamic Banks and Financial Institutions. United Kingdom: Palgrave Macmillan.

Miech, R., Pampel, F., Kim, J., \& Rogers, R. G. (2011). The enduring association between education and mortality: The role of widening and narrowing disparities. American Sociological Review, 76(6), 913-934. https://doi. org/10.1177/0003122411411276

Mohd-Noor, N. S., Ismail, A. G., \& Mohd-Shafiai, M. H. (2018). Shariah Risk: Its Origin, Definition, and Application in Islamic Finance. SAGE Open, 8(2), 1-12. https://doi. org/10.1177/2158244018770237

Nizar, S. (2016). Memperbincangkan Dinamika Intelektual dan Pemikiran Hamka Tentang Pendidikan Islam. Jakarta: Kencana.

Rusmini. (2019). Strategi Pesantren Miftahul Ulum Banyuputih dalam Memberdayakan Perekonomian Masyarakat Banyuputih Kidul Jatiroto Lumajang. Al-Tsaman: Jurnal Ekonomi Dan Keuangan Islam, 1(1), 74-88.

Shofwan, I., Tri, J., Raharjo, A., Rifai, R. C., Fakhruddin, F., Sutarto, J., Utsman, U., Arbarini, M., Suminar, T., Mulyono, S. E., Kisworo, B., Malik, A., Yusuf, A., Ilyas, I., Desmawati, L., Chairul, M., \& Umanailo, B. (2019). Non-Formal Learning Strategy Based On Tahfidz And Character In The Primary School. International Journal of Scientific \& Technology Research, 8(10), 1987-1992

Shofwan, I., Widhanarto, G. P., \& Tristanti, T. (2019). Implementasi pembelajaran nonformal pada sekolah dasar Quran Hanifah di Kota Semarang. JPPM (Jurnal Pendidikan dan Pemberdayaan Masyarakat), 6(1), 1-10. https://doi. org/10.21831/jppm.v6i1.23434

Soerjono, S. (2012). Sosiologi Suatu Pengantar. Jakarta: Rajawali Pers.

Subramanian, S. V., Huijts, T., \& Avendano, M. (2010). Self-reported health assessments in the 2002 World Health Survey: How do they correlate with education? Bulletin of the World Health Organization, 88(2), 131-138. https:// doi.org/10.2471/BLT.09.067058

Sugiyono. (2011). Metode Penelitian Pendidikan: Pendekatan Kuantitatif, Kualitatif dan $R \& D$. Bandung: Alfabeta.

Suharto, E. (2010). Membangun Masyarakat Memberdayakan Rakyat. Jakarta: Refika Aditama.

Theresia, A. (2014). Pembangunan Berbasis Masyarakat. Bandung: Alfabeta.

Ubaidillah, U. (2010). Pandangan masyarakat terhadap pesantren (studi kasus di desa Tlogorejo kecamatan Karangawen kabupaten Demak). Semarang: IAIN Walisongo.

Zimmerman, M. A. (2000). Empowerment theory. In Handbook of community psychology. UK: Springer.

Zubaedi, P. M. B. P. (2007). Kontribusi Fiqih Sosial Kiai Sahal Mahfudh dalam Perubahan Nilai-nilai Pesantren. Semarang: Pustaka Pelajar. 